\title{
Effect of Health Problems on Work Likert Scale
}

National Cancer Institute

\section{Source}

National Cancer Institute. Effect of Health Problems on Work Likert Scale. NCI

Thesaurus. Code C123292.

A scale for the subjective scoring of the effect of an individual's health problems on their ability to work that ranges from 0: Health problems had no effect on my work to 10 : Health problems completely prevented me from working. 